\title{
PELATIHAN KOMUNIKASI EFEKTIF DALAM RANGKA MEMBINA KETERAMPILAN BERWIRAUSAHA SISWA DI SMPN 4 SINTANG
}

\author{
Anna Marganingsih, Emilia Dewiwati Pelipa, Sri Astuti \\ STKIP Persada Khatulistiwa \\ anna.marganingsi@stkippersada.ac.id,pelipaemilia@stkippersada.ac.id, sriastuti@stkippersada.ac.id
}

\begin{abstract}
The progress of a country needs to be supported by the lack of entrepreneurs. UN statement states that a country will be able to build if have entrepreneurs as much as $2 \%$ of the population. The fact shows that the number of entrepreneurs in Indonesia has not reached that number. This becomes anxiety that needs to be addressed. To become a successful entrepreneur, needs to be inculcated soul and entrepreneurship skills early on all levels of education. One level of education that is targeted in the program of community service is the level of secondary education is SMPN 4 Sintang. Class VII is considered most appropriate to provide effective communication training so that from the beginning they have good communication skills to support their entrepreneurship skills. The purpose of this community service is to provide effective communication training in order to foster the skills of entrepreneurship of grade VII students at SMPN 4 Sintang. The method used is counseling and improving students' understanding of Grade VII SMPN 4 Sintang on the importance of community contribution in the progress of the Indonesian state by becoming entrepreneurs, improving entrepreneurship skills through effective communication kiomunikasi and enhancing school understanding on the importance of providing trainings that equip students with entrepreneurial skills since early. Student response to the training implementation equal to 77,12\% into good category. This means that students' response to the training activities in affection, conation and cognition is good.
\end{abstract}

Keywords: Effective Communication Training, Entrepreneurship Skill

\begin{abstract}
Abstrak: Kemajuan suatu negara perlu didukung oleh kebaradaan para wirausahawan. Pernyataan PBB mengemukakan bahwa suatu negara akan mampu membangun apabila memiliki wirausahawan sebanyak $2 \%$ dari jumlah penduduknya. Kenyataan menunjukkan bahwa jumlah wirausahawan di Indonesia belum mencapai angka tersebut. Hal ini menjadi keresahan yang perlu disikapi. Untuk menjadi wirausahawan sukses, perlu ditanamkan jiwa dan keterampilan berwirausaha sejak dini pada semua jenjang pendidikan. Salah satu jenjang pendidikan yang menjadi sasaran dalam program pengabdian kepada masyarakat ini adalah jenjang pendidikan menengah yaitu SMPN 4 Sintang. Kelas VII dianggap paling tepat untuk memberikan pelatihan komunikasi efektif agar sejak awal mereka memiliki keterampilan berkomunikasi yang baik untuk mendukung keterampilan berwirausaha mereka. Tujuan kegiatan pengabdian kepada masyarakat ini adalah untuk memberikan pelatihan komunikasi efektif dalam rangka membina keterampilan berwirausaha siswa kelas VII di SMPN 4 Sintang. Metode yang digunakan adalah penyuluhan dan peningkatan pemahaman siswa Kelas VII SMPN 4 Sintang tentang pentingnya kontribusi masyarakat dalam kemajuan negara Indonesia dengan menjadi wirausahawan, peningkatan keterampilan berwirausaha melalui pelatihan kiomunikasi efektif dan peningkatan pemahaman sekolah tentang pentingnya memberikan pelatihan-pelatihan yang membekali siswa dengan keterampilan berwirausaha sejak dini. Respon siswa terhadap pelaksanaan pelatihan sebesar 71,12\% masuk dalam kategori baik. Artinya secara respon siswa terhadap kegiatan pelatihan secara afeksi, kansi dan kognisi adalah baik.
\end{abstract}

Kata kunci: Pelatihan Komunikasi Efektif, Keterampilan Berwirausaha 


\section{PENDAHULUAN}

Suatu pernyataan yang bersumber dari PBB menyatakan bahwa suatu negara akan mampu membangun apabila memiliki wirausahawan sebanyak $2 \%$ dari jumlah penduduknya. Jadi, jika negara kita berpenduduk 200 juta jiwa, maka wirausahawannya harus lebih kurang sebanyak 4 juta. Katakanlah jika kita hitung semua wirausahawan Indonesia mulai dari pedagang kecil sampai perusahaan besar ada sebanyak 3 juta, tentu bagian terbesarnya adalah kelompok kecil-kecil yang belum terjamin mutunya dan belum terjamin kelangsungan hidupnya (kontinuitasnya).

Siapa yang dapat digolongkan wirausahawan menurut J.A. Schumpeter adalah seorang inovator, sebagai individu yang mempunyai kenalurian untuk melihat benda materi sedemikian rupa yang kemudian terbukti benar, mempunyai semangat, kemampuan dan pikiran untuk menaklukkan cara berpikir lamban dam malas. Seorang wirausahawan mempunyai peran untuk mencari kombinasi-kombinasi baru, yang merupakan gabungan dari lima hal, yaitu:

1. Pengenalan barang dan jasa baru

2. Metode produksi baru

3. Sumber bahan mentah baru

4. Pasar-pasar baru dan

5. Organisasi industri baru

Keberhasilan pembangunan yang dicapai oleh negara Jepang ternyata disponsori oleh wirausahawan yang telah berjumlah $2 \%$ tingkat sedang, berwirausaha kecil sebanyak 20\% dari jumlah penduduknya. Inilah kunci keberhasilan pembangunan negara Jepang. (Heidjrachman Ranu Pandojo).

Jika negara kita harus menyediakan 3 juta wirausahawan besar dan sedang, maka kita masih harus mencetak 30 juta wirausahawan kecil. Ini adalah suatu peluang besar yang menantang generasi muda untuk berkreasi. Mengadu ketrampilan membina wirausahawan dalam rangka turut berpartisipasi membangun negara.

Usaha untuk membina keterampilan berwirausaha tersebut memang harus dimulai sedini mungkin di berbagai jenjang pendidikan. Berbagai upaya perlu dilakukan untuk membekali para peserta didik dengan pelatihanpelatihan agar kelak mereka memiliki keterampilan berwirausaha.

Salah satu pelatihan yang sangat diperlukan untuk membina ketrampilan berwirausaha adalah pelatihan komunikasi efektif. Komunikasi efektif yaitu komunikasi yang mampu menghasilkan perubahan sikap (attitude change) pada orang lain yang bisa terlihat dalam proses komunikasi. Kemampuan melakukan komunikasi efektif akan membantu seseorang untuk berwirausaha sebab untuk menjadi wirausahawan yang sukses memerlukan keahlian komunikasi yang baik dengan orang lain.

Marganingsih, dkk, Pelatihan Komunikasi... 12. 
Permasalahan yang ada di SMPN 4 Sintang adalah siswa sebagai individu-individu yang memiliki potensi jiwa berwirausaha kurang dibina untuk memiliki keterampilan berwirausaha. Belum ada pelatihan-pelatihan yang membekali para siswa tersebut dengan kemampuan berkomunikasi yang efektif yang merupakan modal utama untuk mendukung keterampilan berwirausaha mereka. Oleh sebab itu, kami mengajukan Laporan Pengabdian kepada Masyarakat dengan Judul: Pelatihan Komunikasi Efektif untuk Membina Keterampilan Berwirausaha Siswa Kelas VII SMPN 4 Sintang.

Tujuan pengabdian dalam bentuk laporan pengabdian pada masyarakat ini adalah untuk memberikan informasi tentang Komunikasi Efektif dalam rangka Membina Keterampilan Berwirausaha Bagi Siswa Kelas VII SMPN 4 Sintang dan respon siswa terhadap pelaksanaan Pelatihan Komunikasi Efektif dalam rangka Membina Keterampilan Berwirausaha Bagi Siswa Kelas VII SMPN 4 Sintang. Sasaran Program dalam Penyuluhan Pendidikan ini siswa-siswi yang sedang memulai pendidikan di jenjang menengah pertama yaitu siswa kelas VII SMPN 4 Sintang, Kecamatan Sintang, Kabupaten Sintang, Provinsi Kalimantan Barat. Solusi yang ditawarkan untuk mengatasi masalah yang ada adalah dengan menyelenggarakan Pelatihan Komunikasi Efektif. Luaran yang diharapkan dari pelaksanaan kegiatan Pengabdian kepada Masyarakat ini adalah peningkatan pemahaman siswa Kelas VII SMPN 4 Sintang tentang pentingnya kontribusi masyarakat dalam kemajuan negara Indonesia dengan menjadi wirausahawan, peningkatan keterampilan berwirausaha melalui pelatihan komunikasi efektif dan peningkatan pemahaman sekolah tentang pentingnya memberikan pelatihanpelatihan yang membekali siswa dengan keterampilan berwirausaha sejak dini.

\section{METODE PELAKSANAAN}

Metode pelaksanaan kegiatan Pengabdian kepada Masyarakat ini mengikuti beberapa tahap berikut:

1. Perencanaan

Perencanaan meliputi penyusunan proposal, sosialisasi kegiatan ke SMPN 4 Sintang dan penyusunan materi pelatihan.

2. Pelaksanaan

Pelaksanaan kegiatan melibatkan dosen tim sebagai pemateri dan mahasiswa sebagai panitia pelaksana. Peserta pelatihan adalah siswa kelas VII SMPN 4 Sintang. Waktu pelaksanaan pelatihan adalah 1 (satu) hari di SMPN 4 Sintang pada Hari Senin, tanggal 11 Desember 2017

3. Pengolahan data

Pengolahan data penelitian meliputi penilaian hasil pelaksanaan pelatihan melalui analisis angket yang disebarkan 


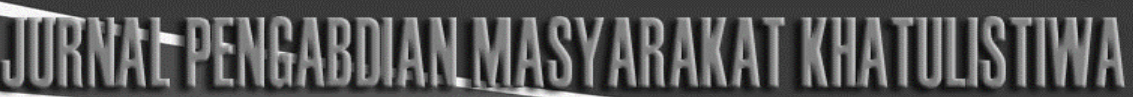

kepada peserta pelatihan setelah pelaksanaan pelatihan

Alat pengumpulan data yang digunakan dalam pengabdian ini adalah Lembar Kerja Siswa untuk mengobservasi pelaksanaan pelatihan dan angket untuk mengukur respon siswa terhadap pelaksanaan pelatihan. Data yang diperoleh diolah secara deskripstif dan dinarasikan pada bagian hasil dan pembahasan.

Materi yang disampaikan dalam pelatihan adalah sebagai berikut:

\section{Pengertian Komunikasi Efektif}

Komunikasi Efektif adalah keterampilan yang paling penting dalam hidup. Komunikasi Efektif juga merupakan sarana untuk menjalin (HAM) Hubungan Antar Manusia yang efektif, sarana untuk saling berbagi informasi., sarana pengenalan diri dan sering dianggap sebagai hal yang otomatis seperti halnya bernafas. Pandai berkomunikasi berarti pandai mengorganisasikan buah pikiran dalam bentuk ucapan yang jelas. Komunikasi yang baik dan efektif diikuti dengan perilaku jujur, konsisten dalam pembicaraan akan sangat membantu seorang wirausaha dalam mengembangkan usaha yang ditekuninya.

Komunikasi menurut Kasim diartikan sebagai pemberitahuan sesuatu (pesan) dari satu pihak ke pihak lain dengan menggunakan suatu media. Komunikasi efektif terjadi apabila sesuatu (pesan) yang diberitahukan oleh komunikator dapat diterima dengan baik atau sama oleh komunikan, sehingga tidak terjadi salah paham atau salah persepsi.

Sebagai makhluk sosial, manusia sering berkomunikasi satu sama lain. Komunikasi merupakan prasyarat dalam berkehidupan manusia, sebab tanpa komunikasi, interaksi antar manusia baik personal, kelompok maupun organisasi tidak akan terwujud. Arifin dalam Kasim(2011) menyampaikan bahwa aksi dan reaksi antar manusia ini disebut tindakan komunikasi. Penyampai pesan dalam komunikasi disebut komunikator dan penerima pesan disebut komunikan.

Tindakan komunikasi dapat dilakukan dengan berbagai cara, baik secara verbal (dalam bentuk kata-kata, lisan atau tulisan), ataupun non verbal (tidak dalam bentuk kata-kata, misal; tingkah laku, gambar-gambar dan bentuk lainnya yang mengandung arti. Komunikasi juga dapat disampaikan secara langsung dan tidak langsung. Komunikasi tidak langsung adalah tindakan komunikasi yang dilakukan tidak secara perorangan tetapi melalui medium atau alat perantara tertentu. Misalnya menyampaikan informasi melalui surat kabar, majalah, radio dan lain-lain (Arifin dalam Kasim; 2011).

Komunikasi berasal dari kata "Communicare" (bahasa Latin) yang artinya memberitahukan. Sedangkan menurut bahasa Inggris disebut "Communication" yang artinya 
suatu pertukaran informasi, konsep, ide, perasaan antara dua atau lebih.

\section{Prinsip-prinsip Komunikasi}

Menciptakan komunikasi yang efektif tentu tidak mudah. Sebelum melakukan komunikasi ada beberapa hal yang harus diperhatikan. Menurut Viyanti (20125) ada 5 prinsip komunikasi yang harus dipahami. Prinsip tersebut adalah respect, empathy, Audible, Clarity, Humble (REACH). Masing-masing dari prinsip-prinsip tersebut akan dijelaskan sebagai berikut.

\section{a. Respect}

Respect adalah memberikan perasaan positif atau penghormatan diri kepada lawan bicara. Pada dasarnya semua orang ingin dihargai dan dihormati, ini salah salah satu bentuk kebutuhan kita semua. Maslow dalam teorinya menjelaskan bahwa manusia itu butuh dihargai dan diakui oleh orang lain. Dale Carnegie dalam Viyanti (2012) dalam bukunya How to Win Friends and Influence People, juga menjelaskan bahwa rahasia terbesar yang merupakan salah satu prinsip dasar dalam berurusan dengan manusia adalah dengan memberikan penghargaan yang jujur dan tulus. Karena itulah prinsip menghormati ini harus selalu kita pegang dalam berkomunikasi dengan orang lain.
There will be no respect without trust and there is no trust without integrity (Tidak akan ada rasa hormat tanpa kepercayaan dan tidak ada kepercayaan tanpa integritas) - Samuel Johnson.

b. Empathy

Empathy adalah kemampuan untuk menempatkan diri pada situasi atau kondisi yang dihadapi orang lain. Atau dengan kata lain kita harus mampu merasakan apa yang dirasakan oleh orang lain. Dengan begitu kita akan lebih mudah melakukan komunikasi dengan baik sesuai dengan kondisi psikologis lawan bicara. Untuk memiliki empati yang tinggi Anda harus menempatkan diri Anda sebagai pendengar yang baik, bahkan sebelum orang lain mendengarkan kita.

Hal ini diperkuat oleh Steven Covey dalam Viyanti (2012) dalam bukunya The Seven Habit Of Highly Effective People Menjelaskan salah satu dari tujuh kebiasaan manusia efektif adalah mengerti terlebih dahulu, baru dimengerti (Seek First to Understand). Jadi kembangkan prinsip ini dengan baik banyaklah mendengar dan memahami dengan begitu orang lain juga akan mudah mendengar dan memahami kita.

c. Audible 
Audible mengandung makna pesan harus dapat didengarkan dan dapat dimengerti. Untuk bisa menjalankan prinsip ini ada beberapa hal yang harus kita lakukan yaitu,

Pertama, pesan harus mudah dipahami, menggunakan bahasa yang baik dan benar sesuai dengan pemahaman lawan bicara. Kedua, sampaikan yang penting. Tidak usah bertele-tele dalam menyampaikan pesan. Ketiga, gunakan bahasa tubuh Anda. Mimik wajah, kontak mata, gerakan tangan dan posisi badan bisa dengan mudah terbaca oleh lawan bicara Anda. Jadi tunjukkan kesejatian Anda dengan mengoptimalkan bahasa tubuh saat menyampaikan pesan. Keempat, gunakan ilustrasi atau contoh. Itulah empat hal yang bisa kita lakukan untuk melaksanakan prinsip audible dalam komunikasi yang efektif.

\section{d. Clarity}

Clarity adalah kejelasan dari pesan yang kita sampaikan. Salah satu penyebab munculnya salah paham antara satu orang dengan yang lain adalah informasi yang tidak jelas yang mereka terima. Informasi seperti ini mengaburkan banyak orang. Sehingga orang pun berspekulasi atau menafsirkan sendiri atas apa yang mereka dengar. Dan akibatnya jika penafsirannya salah, bisa menimbulkan masalah. Dalam komunikasi efektif ini harus kita hindari. Usahakan betul bahwa pesan yang Anda sampaikan jelas dan tidak menimbulkan bias atau spekulasi dari lawan bicara.

Langkah terbaik sebelum melakukan komunikasi adalah dengan menetapkan tujuan secara jelas dan perjelas intonasi suara Anda. Sadari bahwa Anda punya tujuan dalam berkomunikasi dan sampaikan pesan Anda dengan suara intonasi suara yang baik, tidak harus keras yang penting bisa didengar oleh lawan bicara.

Jadi sampaikan apa yang harus Anda sampaikan. Tapi diamlah kalau Anda masih ragu atau belum tahu betul dengan apa yang akan Anda sampaikan.

\section{e. Humble}

Sikap ini merupakan unsur yang terkait dengan hukum pertama untuk membangun rasa menghormati orang lain, biasanya didasari oleh sikap rendah hati yang kita miliki. Rendah hati dalam komunikasi akan menumbuhkan respect. Artinya, rasa hormat yang Anda tunjukkan dengan kerendahan hati akan mengakibatkan lawan bicara kita hormat dan menghargai diri kita. Jika sudah seperti ini maka yang namanya 
komunikasi efektif akan tercapai dengan baik.

Demikianlah lima

prinsip

komunikasi efektif yang bisa kita terapkan. Raih kesuksesan Anda dengan komunikasi yang lebih baik lebih efektif dalam berbagai kesempatan.

\section{Pentingnya Komunikasi dalam}

\section{berwirausaha}

Wirausaha dikenali bukan dalam isolasi, melainkan dalam berkomunikasi dan interaksi dengan pihak lain di luar dirinya sendiri. Apa sebabnya? Karena wirausaha itu tidak hidup sendirian. Dari adanya berkomunikasi dan interaksi, akan terbentuk kepribadian yang mencakup perilaku, sikap, dan sistem nilai. Kehidupan para wirausaha sehari-hari selalu terlibat dengan menerima dan memberi informasi melalui komunikasi. Oleh sebab itu, dengan adanya komunikasi di dalam dunia bisnis sangat penting sekali untuk keberhasilan di dalam kegiatan usahanya.

Sudah jelas bahwa salah satu yang paling penting bagi para wirausahawan untuk mendapatkan sukses di dalam bisnis adalah dengan berkomunikasi dan interaksi. Jika tidak dapat berkomunikasi maka tidak mungkin bagi seorang wirausahawan dapat memperoleh kesempatan berbisnis, baik untuk menciptakan ide-ide, gagasan, maupun cara mengembangkan usahanya.
Berkomunikasi yang dianggap baik adalah berkomunikasi yang berlangsung secara timbal balik dan terus menerus dapat menciptakan saling pengertian semua pihak. Dengan demikian, komunikasi yang berlangsung secara timbal balik, akan bermanfaat dalam setiap kesempatan berwirausaha untuk mencapai tujuan.

Begitu pula dengan berkomunikasi di dalam berbisnis akan mendapatkan kesempatan sukses jika disertai dengan perkembangan teknologi. Di dalam pembinaan kemampuan berkomunikasi ada tiga aspek yang perlu diperhatikan oleh setiap wirausahawan, yaitu:

1) Berkomunikasi harus dipandang sebagai proses.

2) Berkomunikasi harus menyangkut manusia dan bukan manusia.

3) Berkomunikasi harus menyangkut informasi.

Berkomunikasi secara efektif akan menghasilkan buah pildran yang positif untuk memecahkan permasalahan dalam wirausaha, yaitu:

1) Memberi kesempatan berbicara kepada lawan bicara.

2) Bertatap muka secara sopan dan ramah tamah.

3) Berbicara secara jelas, dimengerti, dan jangan berbisik.

4) Menghayati pokok permasalahan yang akan disampaikan. 
5) Menghimpun karakteristik wirausaha yang berhasil di dalam usahanya.

\section{Proses berkomunikasi}

Proses berkomunikasi dapat diklasifikasikan sebagai berikut:

1) Proses komunikasi primer

Proses komunikasi primer adalah proses penyampaian pikiran oleh wirausaha (komunikator) kepada masyarakat konsumen (komunikan) dengan menggunakan lambang-lambang sebagai media atau saluran.

2) Proses komunikasi sekunder

Proses komunikasi sekunder adalah proses penyampaian pesan oleh seorang wirausaha (komunikator) kepada masyarakat konsumen (komunikan) dengan menggunakan alat sebagai sarana. Seorang wirausaha menggunakan media, karena masyarakat konsumen sangat jauh tempat tinggalnya dan sangat banyak. Apabila masyarakat konsumen (komunikan) sangat jauh tempat tinggalnya, maka sebagai alat berkomunikasi menggunakan surat, telepon, telegram, dan lain sebagainya.

3) Proses komunikasi linear

Proses komunikasi linear adalah proses perjalanan dari satu titik ke titik lain secara lurus. Proses komunikasi linear merupakan penyampaian pesan oleh seorang wirausaha (komunikator) kepada masyarakat konsumen (komunikan) sebagai titik terminal. Komunikasi linear ini berlangsung dalam situasi berkomunikasi tatap muka atau melalui alat media.

4) Proses komunikasi sirkular

Proses komunikasi sirkular adalah proses terjadinya umpan balik (feed back). Terjadinya umpan balik (feed back) adalah adanya arus pesan dari seorang wirausaha (komunikator) mengalir kepada masyarakat konsumen (komunikan). Adakalanya umpan balik itu mengalir dari masyarakat konsumen (komunikan) kepada wirausaha (komunikator)."

Berdasarkan pemaparan di atas, wirausaha dapat menggunakan berbagai proses komunikasi untuk mengembangkan usahanya. Keempat proses komunikasi di atas dapat ditempuh wirausaha dalam menjalankan bisnisnya. Jika komunikasi yang dilakukan efektif, tentunya usaha bisnis yang dijalankana akan berkembang.

\section{HASIL DAN PEMBAHASAN}

Kegiatan Penyuluhan dan Pelatihan Komunikasi Efektif dalam Rangka Membina Keterampilan Berwirausaha Siswa Kelas VII dan VIII SMPN 4 Sintang dilaksanakan pada ari Senin, tanggal 11 Desember 2017 pukul 08.00 wib -11.30 wib. Jumlah peserta adalah 25 orang.

\section{Penyampaian Materi}




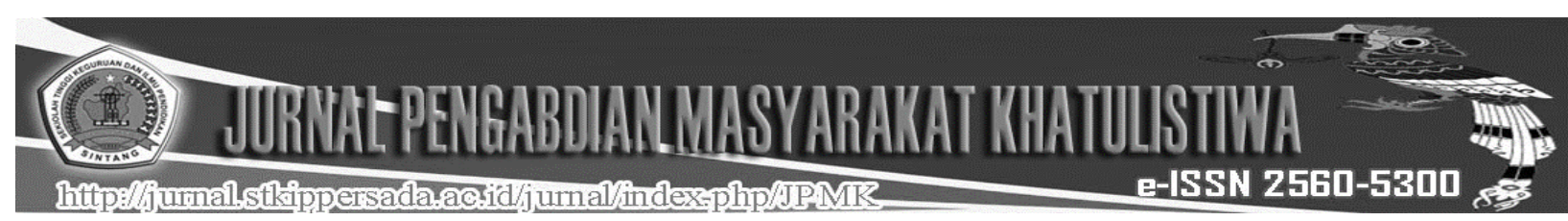

Pemateri menyampaikan materi tentang

Komunikasi Efektif dalam rangka membina

Keterampilan Berwirausaha Siswa.

\section{Pelaksanaan Pelatihan Komunikasi}

\section{Efektif dalam Membina Keterampilan}

\section{Berwirausaha}

Setelah penyampaian materi di atas, siswa dibagi ke dalam 4 kelompok dengan anggota masing-masing kelompok 6-7 orang. Masingmasing kelompok diberi tugas sebagai berikut:

Kelompok I : mencari/membuat contoh proses komunikasi primer untuk memasarkan suatu produk

Kelompok II : mencari/membuat contoh proses komunikasi sekunder untuk memasarkan produk

Kelompok III : mencari/membuat contoh proses komunikasi linier untuk memasarkan suatu produk

Kelompok IV : mencari/membuat contoh proses komunikasi sirkular untuk mendapatkan umpan balik atas suatu produk

\section{Hasil Pelatihan}

Setiap kelompok setelah mengerjakan tugas yang diberikan, selanjutnya mempresentasikan dan menjelaskan hasil pekerjaan kelompok.

Kelompok I: Anggota Kelompok I terdiri dari Angelina, Yuni Karmila, Yuyun Aulia, Rika Hidayat, Nurul Agustian dan Lutvia Dwi. Kelompok ini menyajikan gambar iklan sebagai berikut:

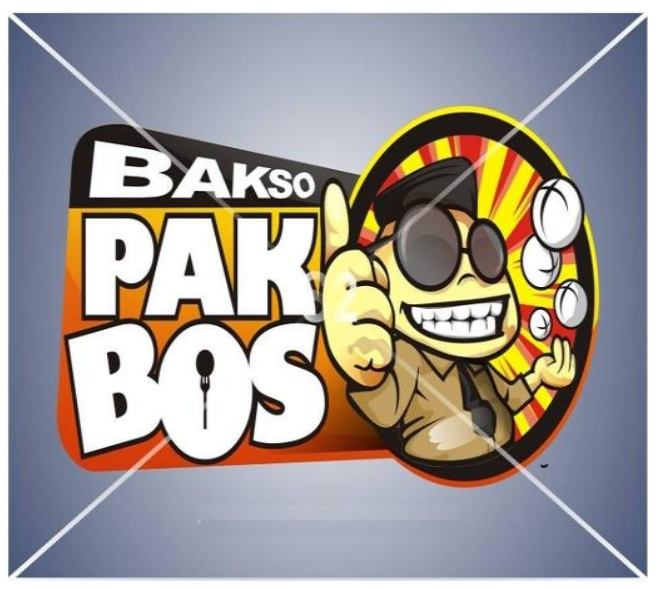

Gambar ini merupakan iklan produk bakso.

Gambar ini merepresentasikan proses komunikasi primer.

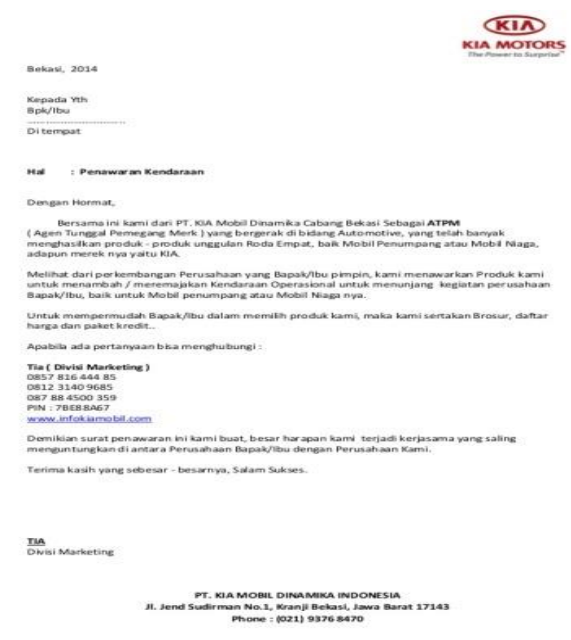

Kelompok II. Anggota Kelompok II terdiri dari Hilda, Elvianti Jesika, Damayanti, Irsalina, Rifa Safitri dan Medisa Apriyani. Kelompok ini menyajikan gambar iklan sebagai berikut:

Kelompok II mempresentasikan dengan baik contoh proses komunikasi sekunder dalam bentuk surat penawaran produk kendaraan 


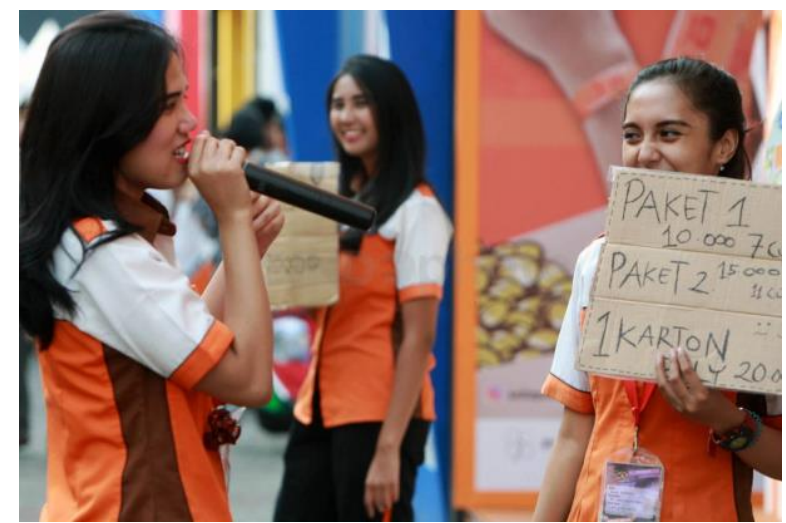

Kelompok III. Anggota Kelompok III terdiri dari Alika, Dewi Sartika, Wirda Yanti, Yulita, Fitri Ana dan Tarisya Rinjani. Kelompok ini menyajikan gambar iklan sebagai berikut:

Gambar ini merepresentasikan proses komunikasi linier penawaran produk kepada pelanggan.

Kelompok IV. Anggota Kelompok IV terdiri dari Jessia, Fenny Nur M., Siska S., Siti Khusnul, Nur Aswinda, Cici Ayu dan Shilvia Indriani. Kelompok ini menyajikan gambar iklan sebagai berikut:

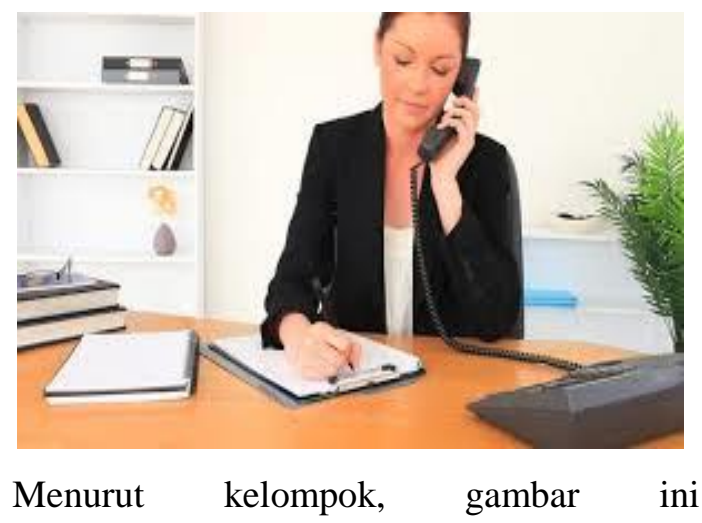
merepresentasikan petugas pemasaran produk sedang menelpon elanggan untuk mendapatkan umpan balik dari pelanggan tentang kepuasan pelanggan atas produk perusahaan yang telah dibelinya.

\section{Respon Siswa}

Setelah mengikuti pelatihan, siswa dibagi angket untuk mendapatkan umpan balik atas ppelaksanaan kegiatan pelatihan yang dilaksanakan. Hasil angket siswa adalah sebagai berikut:

$$
\begin{aligned}
N A & =\frac{\text { Skor yang didapat siswa }}{\text { Skor maksimum }} \times 100 \% \\
N A & =\frac{1928}{2500} \times 100 \% \\
N A & =77,12 \%
\end{aligned}
$$

Berdasarkan analisis hasil perhitungan diperoleh hasil sebesar 77, $12 \%$.

\section{Pembahasan}

\section{a. Pelatihan Komunikasi Efektif}

Komunikasi merupakan prasyarat dalam berkehidupan manusia, sebab tanpa komunikasi, interaksi antar manusia baik personal, kelompok maupun organisasi tidak akan terwujud. Dalam berwirausaha, komunikasi mutlak diperlukan. Berkaitan dengan menemukan ide, mengelola unit usaha, memasarkan produk dan sebagainya, wirausaha perlu melakukan komunikasi. Komunikasi yang efektif akan sangat mendukung pencapaian hasil dan perngembangan usaha.

Keterampilan berwirausaha tidak serta merta dimiliki setiap individu. Perlu berbagai usaha untuk mengembangkannya. Salah satu yang 
perlu dilakukan adalah dengan mengikuti/menyelenggarakan

pelatihanpelatihan. Harapan dari pelatihan yang diikuti maupun diselenggarakan adalah menghasilkan wirausahawan-wirausahawan baru yang akan mengisi peluang kebutuhan negara akan wirausahawan baru untuk meningkatkan kemajuan negara.

Pengenalan kewirausahawaan melalui jenjang pendidikan dirasa sangat tepat untuk menumbuhkan jiwa wirausaha. Siswa sejak dini perlu dilatih untuk memiliki jiwa wirausaha sehingga akan mengarahkan siswa sebagai wirausahawan yang terampil. Oleh sebab itu, pelatihan ini diselenggarakan untuk memberikan pelatihan komunikasi efektif dalam membina keterampilan berwirausaha siswa kelas VII di SMPN 4 Sintang.

Hasil pelaksanaan pelatihan menunjukkan bahwa setelah siswa menerima materi yang telah disampaikan kemudian diminta untuk mempresentasikan dan menjelaskan hasil pekerjaan mereka, para siswa tersebut mampu melaksanakan proses komunikasi secara efektif. Tugas membuat/mencari contoh proses komunikasi yang diberikan kepada masingmasing kelompok dapat diselesaikan dengan baik dan dipresentasikan dengan lancar.

Setelah pelaksanaan pelatihan, siswa menyadari pentingnya kontribusi masyarakat dalam kemajuan negara Indonesia dengan menjadi wirausahawan, pentingnya meningkatkan keterampilan berwirausaha melalui pelatihan kiomunikasi efektif dan perlunya meningkatkan pemahaman sekolah tentang perlunya menyelenggarakan pelatihanpelatihan yang membekali siswa dengan keterampilan berwirausaha sejak dini.

\section{b. Respon Siswa terhadap Pelaksanaan} Pelatihan Komunikasi Efektif dalam rangka membina Keterampilan Berwirausaha Siswa

Berdasarkan hasil analisis data diperoleh bahwa skor total respon siswa adalah $77,12 \%$. Nilai tersebut kemudian dikonsultasikan pada tabel interprestasi hasil angket berikut:

\begin{tabular}{|c|c|}
\hline $\begin{array}{c}\text { Interval } \\
\text { Persentase }\end{array}$ & Kategori \\
\hline $\mathbf{8 6 - 1 0 0}$ & Baik \\
\hline $\mathbf{7 6 - 8 5}$ & Baik \\
\hline $\mathbf{5 6 - 7 5}$ & Cukup \\
\hline $\mathbf{1 0 - 5 5}$ & Kurang \\
\hline
\end{tabular}

Sumber : Nurgiyantoro (2011: 253)

Nilai angket sebesar 77, $12 \%$ berada pada rentang 76-85 yang artinya masuk dalam kategori BAIK. Item-item dalam angket berisi pernyataan afeksi, kognisi dan konasi siswa terhadap pelaksanaan pelatihan komunikasi efektif dalam rangka membina keterampilan berwirausaha. Dengan demikian dapat disimpulkan bahwa respon siswa atas pelaksanaan kegiatan 


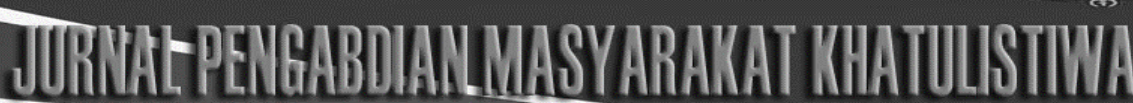

E-ISSN 25ED-5300

http://jurnalstlkippersada.ac 1 id/jurnal/index:php/JPMK

pelatihan komunikasi efektif dalam rangka membina keterampilan berwirausaha adalah baik.

\section{KESIMPULAN}

Berdasarkan kegiatan pelatihan

komunikasi efektif dalam rangka membina

keterampilan berwirausaha pada Siswa

Kelas VII SMPN 4 Sintang diperoleh

kesimpulan sebagai berikut:

1. peningkatan pemahaman siswa Kelas VII SMPN 4 Sintang tentang pentingnya kontribusi masyarakat dalam kemajuan negara Indonesia dengan menjadi wirausahawan, peningkatan keterampilan berwirausaha melalui pelatihan komunikasi efektif dan peningkatan pemahaman sekolah tentang pentingnya memberikan pelatihan-pelatihan yang membekali siswa dengan keterampilan berwirausaha sejak dini.

2. Respon siswa terhadap pelaksanaan pelatihan sebesar $77,12 \%$ masuk dalam kategori baik. Artinya secara respon siswa terhadap kegiatan pelatihan secara afeksi, kansi dan kognisi adalah baik.

\section{DAFTAR PUSTAKA}

A.W.Wijaya. 2010. Ilmu Komunikasi Pengantar Studi. Jakarta: Rineka Cipta

Deddy, Mulyana. 2010. Human Communication. Bandung: PT Remaja Rosdakarya.

Dwihartanti, Muslikhah. "Penyuluhan tentang Komunikasi yang Efektif bagi Guru TK di Kecamatan Panjatan”. Disampaikan pada kegiatan Pengabdian Kepada Masyarakat Tahun 2004. Universitas Negeri Yogyakarta

Frinces, Z. Heflin. Pentingnya Profesi Wirausaha Di Indonesia. Jurnal Ekonomi \& Pendidikan, Volume 7 Nomor 1, April 2010

Handayani, Tutut. Membangun Komunikasi Efektif Untuk Meningkatkan Kualitas Dalam Proses Belajar Mengajar. TA'DIB. Vol. XVI. No. 02, Edisi November 2011

Kasim, Felix. 2011. Komunikasi efektif. http://repository.maranatha.edu/2548/1/ Komunikasi\%20Efektif.pdf. Diakses 12 Desember 2017.

Umar. 2009. Komunikasi dalam Kewirausahaan. http://umarstain.blogspot.co.id/2009/04/ komunikasi-dalam-kewirausahaan.html. Diakses tanggal 12 Desember 2017

Viyanti, Melok.2012. Prinsip dan Langkahlangkah Komunikasi Yang Efektif. https://melokviyanti.wordpress.com. Diakses tanggal 11 Desember 2017 